\title{
FILOZOFIJA TOME AKVINSKOG
}

\author{
Arhe XVI, 31/2019 \\ UDK 172 Thomas Aquinas \\ DOI https://doi.org/10.19090/arhe.2019.31.7-14 \\ Originalni naučni rad \\ Original Scientific Article
}

\author{
MILENKO A. PEROVIĆ ${ }^{1}$ \\ Univerzitet u Novom Sadu, Filozofski fakultet
}

\section{POLITIČKA FILOZOFIJA TOME AKVINSKOG}

\begin{abstract}
Sažetak: Autor izlaže osnovne stavove političko-filozofske koncepcije Akvinskog. U prvi plan stavlja odnos te koncepcije prema poimanju politike kod Aristotela i Avgustina, kao i prema cjelini njegove teološko-filozofske koncepcije. Na tom istraživačkom putu dokazuje da se koncepcija Akvinskog može najproduktivnije razumijeti kao apologija feudalno-hrišćanske slike svijeta.
\end{abstract}

Ključne riječi: Akvinski, filozofija politike, feudalizam, hrišćanstvo

Avgustin je u vremenu nastanka hrišćanske civilizacije smatrao da politika može biti predmet filozofsko-teološke refleksije samo zato što pripada poretku stvaranja. Ona ne izražava niti od nje zavise vodeći praktički, moralni i religijski interesi čovjeka. Proći će niz stoljeća ranog Srednjeg vijeka bez sistemske filozofsko-političke ili teološke refleksije problematike politike, države, oblika uređenja države etc.

Oblikovanjem kasnije srednjovjekovne teološke refleksije potpuno se opoziva avgustinovski odnos prema problemu politike i države na osnovu promjena $u$ povijesnom odnosu između crkve i političke vlasti. Talas jeretičkih pokreta koji je zahvatio Evropu tokom XI-XIII st. u dobroj je mjeri uzdrmao povjerenje u staleško-feudalno

\footnotetext{
${ }^{1}$ E-mail adresa autora: perovic@ff.uns.ac.rs
} 
uređenje. Zbog toga, feudalnom je poretku trebalo novo teorijsko utemeljenje. Dominikanac Toma Akvinski ${ }^{2}$ preuzeo je taj zadatak u vrijeme kada je papstvo doživjelo vrhunac moći u političkoj i duhovnoj konstelaciji Evrope, a vrijeme je iznijelo potrebu za sholastičkom sintezom katoličke teologije.

Visoka sholastika baštinila je dugo trajanje iskustva duhovne i društvene etabliranosti hrišćanstva te prožetosti svih oblika ljudskog životnog ispoljavanja religijskim svjetonazorom. U tom iskustvu povijesna egzistencija država i političkih oblika praksisa nosila je snažni oprirođeni znak hrišćanskosti, nužnosti legitimiranja političke vlasti iz religijskog poslanja, ali i krajnje složenih odnosa u pitanjima crkvenopapskog nasljedstva „trona svetog Petra“, religijske prakse s političkim implikacijama i same političke sfere feudalnih društava. Da bi se održala izvorna hrišćanska okrenutost eshatološkim nadama - prevedena u opšti vertikalni poredak svega što jeste i vertikalni poredak feudalne društvenosti - bili su potrebni novi sintetički misaoni napori u teološkofilozofskom području.

Opšte civilizacijsko opadanje - koje je proisteklo u ranom feudalitetu iz povijesnog susreta rodovsko-plemenske svijesti germanskih naroda i propadajuće rimske civilizacije - u periodu klasičnog feudalizma preokreće se u opšti civilizacijski rast. Tada jača svijest o važnosti politike. Avgustinovo obescjenjivanje politike postalo je anahrono. Kolektivistička običajnosna svijest ranog feudalizma počela se potiskivati novim individualističkim senzibilitetom zapadnog čovjeka. Pravna svijest je otkrivala nedostatnosti lenskog prava. Ekonomska svijest počinje poimati da pored božanske ekonomije tvorenja postoji i ovozemaljska ekonomija koja je vođena lukrativnim interesima. Politička svijest više nije nalazila zadovoljenje u teocentričkoj koncepciji svijeta i teokratskoj koncepciji politike. Osnažila je tako potreba da se preispitaju sva praktička pitanja vremena. U etici je osnažila potreba za obnovom antičke snage promišljanja moralno-etičkog fenomena. U pravnoj nauci počela se shvatati beskrajna vrijednost instituta rimskog prava. U ekonomiju

\footnotetext{
${ }^{2}$ Dominikanski red Katoličke crkve je proklamovao borbu s jeresima „uz pomoć lomača i silogizama.“
} 
prodire svijest o potrebi promišljanja novih ekonomskih robno-novčanih fenomena. Napokon, dinamika novih političkih realnosti potrebovala je novu filozofiju politike. Za sve ove zahtjeve bila je potrebna praktička filozofija aristotelovskog oblika i sistematskog izvođenja, ali koja ne bi ugrožavala temelje hrišćanske vjere.

Toma Akvinski (1224/5-1274) je izložio praktičku filozofiju u sklopu integralnog enciklopedijski planiranog utemeljenja crkvene ideologije sjedinjavanjem aristotelovskog misaonog nasljeđa i hrišćanske teološke doktrine. Pitanja politike, prava, države i zakona obradio je u kapitalnom djelu Summa theologiae (1266-1274), kao i značajnom političko-filozofskom spisu $O$ vladavini kneževa. ${ }^{3}$ Zbiljnost je po Akvinskom hijerarhijski strukturirana od boga preko duhovnog do materijalnog svijeta. U njoj više forme daju život nižima, a ove se njima pokoravaju. Po istom hijerarhijskom principu organizovan je duhovni svijet s pozicijom papstva kao namjesnika božjeg na Zemlji. Tako je organizovan i društveni život. Iz pitanja o ontologijskom odnosu čovjeka i prirode, Akvinski hoće da ontološki zasnuje politiku. Vodi ga uvjerenje da politički praksis reprodukuje djela i namjere ljudskog stvaralaštva u prirodi. Prirodu on ne shvata u kasnijem novovjekovnom smislu kao res extensa. Priroda je izvorište samorazvitka i izraz beskrajnog tvoračkog božjeg uma. Na Aristotelovom tragu, Akvinski iz ovoga stanovišta zasniva razliku posmatračkog odnosa prema prirodi i djelatnog (praktičkog) odnosa te razliku teorijskih i praktičkih znanosti. Akvinski

\footnotetext{
${ }^{3}$ Spis $O$ vladavini knezova (De regno ad regem Cypri, O kraljevskoj vlasti kralja Kipra) najpoznatije je djelo Akvinskog na području filozofije države. Na evropske jezike ovaj naslov je češće priređivan kao $O$ vladavini kneževa (lat. De regimine principum). Djelo je prevedeno na hrvatski jezik pod naslovom $O$ kraljevstvu. Kralju Cipra (De regno. Ad regem Cypri) i objavljeno u knjizi Toma Akvinski, Država, Globus-Zagreb, 1990; str. 47-125; Prijevod i bilješke Tomo Vereš; Nesigurno je datiranje ovoga djela (između 1265. i 1273. god.). Posvećeno je kralju Kipra, ali njegovo ime nije navedeno. Misli se vjerovatno na kralja krstaške države na Kipru Iga III (Igo od Poatjea, fr. Hugues de Poitiers). Djelo ima četiri knjige, a Akvinski se u njemu čvrsto oslanja na Aristotelovu praktičku filozofiju.
} 
od Aristotela preuzima odredbu čovjeka zoon politikon. Izvorna prirodna težnja ljudi je objedinjavanje radi življenja u državnoj zajednici, jer pojedinac ne može samostalno zadovoljiti svoje potrebe. Ovaj prirodni princip u temelju je nastanka države. Način stvaranja države može se objasniti u analogiji s božanskim stvaranjem svijeta. U aktu stvaranja javljaju se stvari kao takve. Slijedi njihova diferencijacija prema funkcijama koje ispunjavaju u okviru raščlanjenog poretka svijeta.

Akvinski provodi prvi pokušaj zasnivanja hrišćanske doktrine politike i države. Pojam politike postaje centralnim u njegovoj izgradnji praktičke filozofije na hrišćanskoj paradigmi, srodno Aristotelovom postavljanju mjesta filozofije politike u praktičkoj filozofiji. Svoju filozofiju politike Akvinski izlaže specifičnom metodom komentatorskog apsolviranja Aristotelove Politike. Prema Aristotelovoj paradigmi, on praktički život - shvaćen prema prirodnom obrascu kretanja od jednostavnih prema složenim stvarima - definiše kao socijalno-djelatni niz koji započinje porodicom pa se preko naselja i grada kreće prema državi i zajednici među narodima.

Istaknuto mjesto u ovim oblicima djelatnog života (grč. bíos praktikós, lat. vita activa) ima državna zajednica (communitas civilitatis). Njen cilj je „opšte dobro.“ Ono je shvaćeno kao obezbjeđivanje svih životnih potreba ljudi i uslova za dostojni, umni život. Ostvarenje ovoga cilja implicira očuvanje feudalno-staleškog poretka sa svim unutrašnjim razlikama političkih, pravnih, ekonomskih i kulturnih statusa različitih društvenih slojeva. Država je najsavršenija među ljudskim zajednicama, jer je značajnija od svake druge. Akvinski određuje politiku kao nauku o državi, tj. društvenu nauku (civilis scientia). Suprotno Avgustinu, ističe potrebu za ovakvom naukom. Kao i Aristotel, politiku smješta u problemski korpus praktičke filozofije. Njena djelatnost ne sastoji se u tvorenju (grč. poiesis, lat. per modum factionis). Nije ona oslonjena ni na djelanje u smislu actio (,unutrašnje zbivanje njezinog nosioca“) u smislu Aristotelovog pojma eethos. Kao što politika nije tvorenje (poiesis), tako ni politička nauka nije poietička filozofija. Isto tako, politička nauka nije ni etika (monastika, kako Akvinski imenuje etiku). Politika je znanost političkog. Političko on shvata kao upravljanje ljudima (ordinatione). Država „zauzima vrhunsko mjesto među svim tvorevinama ljudskog 
razuma, budući da su sve ostale ljudske zajednice upućene na nju“. 4 Akvinski i ovđe pokazuje mjeru svoga duga helenskom poimanju znanja i spoznaje. Prema dignitetu vlastitog predmeta, politika se ima shvatiti kao „najznačajnija među svim praktičkim znanostima“. Filozofija o ljudskim stvarima u njoj postiže svoj puni smisao.

Problem dvostruke pripadnosti čovjeka svjetovnoj i duhovnoj zajednici te podložnosti duhovnoj i svjetovnoj moći, Avgustin je pokušavao riješiti strategijom nadilaženja političkog platonizma. Suočen $\mathrm{s}$ istim problemom, Akvinski opet poseže za iskustvom Aristotelove praktičke filozofije. Ljudsko djelanje raščlanjuje na etiku, ekonomiju i politiku (ethica solitaria ili monastica, oeconomica, politica). Aristotelov pojam politike - strukturiran i mjeren prema kriteriju rangovnog poretka među oblicima ljudskog djelanja, daje Akvinskom mogućnost ograničenog rješenja. Kod Aristotela nije bilo moguće postojanje problema dvojne pripadnosti čovjeka svjetovnom i duhovnom poretku. Za njega su toposi najviše istine i svrhe ljudskog djelanja eupraksija i autarkeja polisa. Da je preuzeo ova dva Aristotelova pojma, Akvinski bi ugrozio sami temelj hrišćanske religije, u prvom redu dogmu o transcendentnom božanskom idealu kao svrsi djelatne egzistencije čovjeka. Koristeći misaoni model izvođenja složenijeg iz jednostavnijeg, on tvrdi da cilj koji je niži po rangu (politički cilj) mora prethoditi cilju koji je viši po rangu. Filozofija politike mora biti ispod spekulativne znanosti (teologije i filozofije), ali i iznad drugih praktičkih znanosti (ekonomije i etike). Ljudska volja i moralni uvid koji je vodi (prudentia, recta ratio) moraju biti u skladu s političkim zakonom. On je uređen prema prirodnom zakonu. Svaka stvar treba da ima udjela u poretku vlastite prirode. Prirodni zakon mora biti uređen prema božanskom zakonu. Politica se javlja kao dio razboritosti (pars prudentiae). Ona vodi moralnu razboritost. Ono moralno mora biti vođeno onim političkim. Politika kao prudencijalno umijeće je vladanje građanstvom (prudentia regnativa). Umijeće se sastoji u zasnivanju poretka (legispositiva,

\footnotetext{
${ }^{4}$ Toma Akvinski, Izabrano djelo, Globus, Zagreb 1981., str. 113;
} 
politica architectonica) i upravljanje njime. U međunarodnim odnosima politička razboritost je „prudentia civilis““.

Značajno je istaći još nekoliko filozofsko-političkih uvida Akvinskog. Realističkim pogledom svog hristijaniziranog aristotelizma, on otklanja ideju države kao rezultata prvobitnog grijeha, ali i ideju o državi kao tvorevini egoizma.

Akvinski je sklon ideji indirektne vlasti crkve nad državom. Država mora imati svoje polje djelanja koje će prolaziti u više polje svrha o kome se stara crkva. Teškoću u ovom uvjerenju stvara činjenica da se u novozavjetnom iskustvu javlja stav da je „svaka vlast od boga“. Stav daje mogućnost tumačenja u korist apsolutnog prava svjetovnih feudalaca na vlast $\mathrm{u}$ državi, što je u suprotnosti s političkim pretenzijama Katoličke crkve. Jednako, to je bio razlog osporavanja ovih pretenzija crkve. Da bi teorijski dokazao prevashodstvo duhovne nad svjetovnom vlašću, Akvinski daje novu koncepciju državne vlasti. Njeni elementi su bit, forma (porijeklo) i korišćenje. Bit vlasti je poredak gospodarenja i potčinjavanja ustanovljen od Boga, pri čemu se volja onih na vrhu hijerarhije vlasti kreće prema najnižim slojevima stanovništva. Po svojoj iskonskoj biti, vlast je božanski institut. Po tome je ona u principu dobra. Ovo ne znači da je svaki vladar postavljen neposredno od boga i da bog izvršava svako djelo vladara. Vladar može biti uzurpator, tiranin ili bezumnik. Kao i svaki čovjek, on ima slobodnu volju te je sposoban da tvori zlo. Konkretni oblik dolaska do vlasti može nekad biti nepravedan i loš. Moguće su i zloupotrebe vlasti. Drugi i treći element vlasti mogu pokazivati odsustvo božanskog karaktera. Događa se to kad se vladar nepravednim sredstvima dokopa vlasti ili kad vlada nepravedno. U oba slučaja, narušava zavjet božji i volju Hristovu. U ovim slučajevima, o porijeklu i korišćenju vlasti treba da sudi crkva. Čak i kad svojim sudovima inicira svrgavanje takvih vladara, crkva ne narušava princip božanskog porijekla vlasti. U stvarima spasenja duše, ne treba se potčinjavati svjetovnoj, nego crkvenoj vlasti. Po Akvinskom, obje ove vlasti „sjedinjavaju se u licu pape, koji stoji na vrhu obje vlasti“. Kao što dio mora biti podređen cjelini, tako i pojedinac mora biti podređen državi. Potonja ljudska svrha ne ostvaruje se u državi, nego u transcendentnom pozivu. 
Poslije dugog niza vijekova - na Aristotelovim podsticajima Akvinski opet u filozofsku diskusiju vraća pitanje o najboljim oblicima vladavine. Obnavljanje ovoga pitanja u kontekstu zrelog feudalizma vrednije je od samih odgovora Akvinskog. I ovđe on ide Aristotelovim tragom. Osnovno obilježje vlasti je pravo izdavanja zakona (vladavina pravednosti) i rad na opštem dobru. To su dva kriterija po kojima se razlikuju valjani od nevaljanih poredaka vlasti. Tri su oblika dobre vladavine (zakonita demokratija, aristokratija i monarhija) i tri loša (demagoška demokratija, oligarhija i tiranija). Dok se Aristotel može slijediti u stavu o tiraniji kao najgorem obliku vlasti, ne može u uvjerenju da je miješano uređenje najbolje. Zato Akvinski, prema realiji vlastite epohe u kojoj dominiraju monarhistički oblici, uzdiže pomoćnu Aristotelovu soluciju o monarhiji i proglašava je najboljim uređenjem, dok se negativno odnosi prema gradskoj republici. Djelatnost monarha srodna je djelatnosti Boga. Bog u poredak svijeta unosi organizaciju, a monarh uspostavlja državu i njome upravlja. Akvinski ovaj stav brani idejom jedinstva. U svijetu vlada jedan bog, u tijelu jedno srce, u duši um, kod pčela matica. Monarhija je najbolji oblik vlasti, jer mnoštvo proizilazi iz jedinstva.

Akvinski brani ideju feudalne nejednakosti ljudi. Jeretički pokreti njegovog vremena isticali su izvornu jevanđeosku ideju jednakosti ljudi u Hristu te na toj osnovi negirali staleške privilegije i bijedni položaj kmetova. Akvinski pokušava ontološki zasnovati stalešku nejednakost postavkom da ona pripada božanskom i prirodnom poretku stvari, da bi se ozbiljili svi stupnjevi savršenstva. „Opšte dobro“ u državi za pretpostavku ima stalešku nejednakost među ljudima. Tezu o prirodnosti ropstva oslanja na stavove Aristotela, Svetog pisma i Avgustina.

\section{LITERATURA}

Akvinski, Toma (1981), Izabrano djelo, Globus, Zagreb,

Akvinski, Toma (1990),Država, prijevod s latinskog izbornika i bilješke Tomo Vereš, Globus Zagreb.

Аквински, Фома (2006-2015), Сумма теологии (lat. Summa theologiae, Summa theologica), Издатель Савин С. А., Москва-Киев. 
Akvinski, Toma (1993-4), Suma protiv pogana (Summa contra gentiles), preveo Augustin Pavlović, Kršćanska sadašnjost, Zagreb.

Augustin, Aurelije (1982), O državi Božjoj, svezak prvi; s latinskog izvornika preveo Tomislav Ladan, Kršćanska sadašnjost, Zagreb.

Koplston, Frederik (1989), Istorija filozofije II: Srednjevekovna filozofija, Augustin-Skot, BIGZ, Beograd.

Maritain, Jacques (2011), Anđeoski naučitelj, Zagreb, Zadruga Enegram.

Vereš, Tomo, (1978), Iskonski mislilac, Dominikanska naklada „Istina“, Zagreb.

Vereš, Tomo (2001), Toma Akvinski i Jacques Maritain o demokraciji, Obnovljeni život 56/1: str. 7-21.

\author{
MILENKO A. PEROVIĆ \\ University of Novi Sad, Faculty of Philosophy
}

\title{
POLITICAL PHILOSOPHY OF THOMAS AQUINAS
}

\begin{abstract}
The author exposes the basic points of Aquinas' politico-philosophical conception. He puts at the forefront the relation of that conception to the Aristotle's and Augustine's concept of politics, as well as to the whole of Aquinas' theologico-philosophical conception. On that research path, the author proves that Aquinas' conception would be most productive understood if it would be understood as the apology of feudal-christian world picture.
\end{abstract}

Keywords: Aquinas, philosophy of politics, feudalism, Christianity

Primljeno: 21.2.2019.

Prihvaćeno: 9.5.2019. 